Int. J. Morphol.,

35(4):1377-1382, 2017.

\title{
Browsing Software of the Head Sectioned Images for the Android Mobile Device
}

\author{
Software de Navegación para el Dispositivo Móvil Android de Imágenes Seccionadas de Cabeza
}

\author{
Seung-Bock Lee'; Beom Sun Chung²; Min Suk Chung²; Cheong Youn ${ }^{3}$ \& Jin Seo Park ${ }^{4}$
}

LEE, S. B.; CHUNG, B.S.; CHUNG, M. S.; YOUN, C. \& PARK, J. S. Browsing software of the head sectioned images for the Android mobile device. Int. J. Morphol., 35(4):1377-1382, 2017.

SUMMARY: The purpose of this research was to enable anyone to learn the sectional anatomy of the head anywhere, anytime by presenting software to browse sectioned images on a Google Android mobile device. Among the 2,343 sectioned images at $0.1 \mathrm{~mm}$ intervals, 234 sectioned images at $1 \mathrm{~mm}$ intervals were chosen. The corresponding 234 segmented images containing 236 head structures were selected. The software of the mobile version was programmed and debugged in the Java programming language. The folders of the sectioned images and segmented images and the txt file of the segmentation data were arranged in the source code of the software. The software was distributed free of charge at the homepage (neuroanatomy.kr) and Google Play Store. After installing the software, the sectioned images and corresponding segmented images could be browsed by touching and swiping the screen. In the medical category of the Google Play Store, the software earned a good reputation. The software of the Android mobile version was usable regardless of the time and place. The software is under the authors' non-commercial policy. Other investigators may modify the mobile software to browse their own images. The mobile version of the software will aid medical students and doctors in learning sectional anatomy.

KEY WORDS: Cross sectional anatomy; Mobile applications; Smartphone; Visible Human Projects.

\section{INTRODUCTION}

Sectional anatomy is the subject to identify and learn the normal body structures in sectional planes (usually, horizontal planes). This is beneficial knowledge for interpreting computer tomographs (CTs) and magnetic resonance images (MRIs). For medical students and doctors to study the sectional anatomy, they utilize atlas books, including the CTs and MRIs or the sectioned images of cadavers (Spitzer \& Whitlock, 1997; Dixon et al., 2015).

Our research team also participated in an atlas publication for the sectional anatomy of brain that consisted of 7 Tesla MRIs, diffuse tensor images of a volunteer, and the sectioned images of a cadaver (Cho et al., 2009). The sectioned images are valuable because they show the real color (48 bits color) and high resolution ( $0.1 \mathrm{~mm}$-sized pixels) (Park et al., 2009). On the sectioned images of the book, hundreds of anatomical structures were labeled. However, the atlas containing numerous images was physically heavy to carry and expensive. To complement for the atlas, the authors developed software to browse the sectioned images of the head on a personal computer as a previous study. Unlike the paper book, the software had no burden of numerous images; the software conveniently browsed the neighboring images. While the anatomical structures were labeled in the book, the structures were segmented and color-coded in the software for automatic demonstration of the structure names (Shin $e t$ al., 2012).

Nowadays, the personal computer is being replaced with mobile devices, the performance of which is being improved rapidly. The medical education field is not an exception (Davies et al., 2012; Franko \& Tirrell, 2012; Rohilla et al., 2016). If the browsing software can be operated on a mobile device, more medical students will benefit from it. Our primary interest was to browse the sectioned images of the human head including the brain on a Google Android environment.

\footnotetext{
${ }^{1}$ Scientific Data Strategy Lab., Scientific Data Research Center, Korea Institute of Science and Technology Information, 245 Daehak-ro, Daejeon, 34141 , Republic of Korea.

${ }^{2}$ Department of Anatomy, Ajou University School of Medicine, 164 Worldcup-ro, Suwon, 16499, Republic of Korea.

${ }^{3}$ College of Engineering, Chungnam National University, 99 Daehak-ro, Dajeon, 34134, Republic of Korea.

${ }^{4}$ Department of Anatomy, College of Medicine, Dongguk University, 87 Dongdae-ro, Gyeongju, 38067, Republic of Korea.
} 
The purpose of this research was to enable anyone to learn sectional anatomy of the head anywhere, anytime by presenting the free software to browse sectioned images on an Android mobile device.

\section{MATERIAL AND METHOD}

In the Visible Korean Project, 2,343 sectioned images (horizontal direction; intervals $0.1 \mathrm{~mm}$; pixel size $0.1 \mathrm{~mm}$; resolution 4,368 X 2,912; 48 bits color; tagged image file format (TIFF)) were prepared by serial-sectioning a male cadaver head (Park et al., 2009). One-hundred seven head structures were selected to be outlined (Table I) (Shin et al., 2012).

The outlines of the structures were drawn in 236 sectioned images at $1 \mathrm{~mm}$ intervals. On Photoshop CS6 version 12 (Adobe Systems, Inc., San Jose, CA, USA), a magnetic lasso tool and lasso tool were used for semiautomatic and manual delineation, respectively. Outlines of every structure were filled with a specific color using an action to make segmented images (TIFF) (Park et al., 2005).

In the sectioned and segmented images, the excessive margins were cropped; the resolution was reduced to 2,070 X 2,064 (pixel size $0.1 \mathrm{~mm}$ ).
On a personal computer working environment, the software for the Android mobile device was programmed and debugged in the programming language, Java (Arnold et al., 2000), using Eclipse Java Development Tools (des Rivières \& Wiegand, 2004). In the source code, two folders and a txt file were designated. The sectioned images and segmented images were placed into two folders, anatomical and segmented, respectively. In the txt file (color.txt), information of the segmented structures (structure names, numbers of uppermost and lowermost images, and red, green, and blue values (0-255) constituting the color) were written (Fig. 1).

After programming and debugging, the source code with the images and the txt file was assembled using export tool of the Eclipse Java Development Tools to make an installation file that was Android application package (APK) format. The installation APK file, accompanied by the source code, was uploaded on the homepage of the corresponding author (Fig. 2).

The installation APK file was also uploaded at the Google Play Store (Fig. 2). Because the Google Play Store receives only software of 100 MBytes or less file size, the resolution of each image was reduced from 2,070 X 2,064 (124 MBytes) to 400 X 458 (41 MBytes) in advance (Butler, 2011).

Table I. 107 outlined structures of the head.

\begin{tabular}{|c|c|}
\hline System & Structures \\
\hline Integumentary (1) & Skin \\
\hline Muscular (44) & $\begin{array}{l}\text { Masseter, lateral pterygoid muscle, medial pterygoid muscle, longus colli, longus capitis, } \\
\text { sternocleidomastoid muscle, rectus capitis posterior major, rectus capitis posterior minor, rectus capitis } \\
\text { anterior, rectus capitis later alis, obliquus capitis superior, obliquus capitis inferior, digastric muscle, } \\
\text { stylohyoid muscle, mylohyoid muscle, sternohyoid muscle, longissimus, trapezius, levator scapulae, } \\
\text { thyrohyoid muscle, splenius capitis, semispinalis cervicis }\end{array}$ \\
\hline Skeletal (10) & $\begin{array}{l}\text { Cranium without mandible, mandible, hyoid bone, first cervical vertebra, second cervical vertebra, third } \\
\text { cervical vertebra, fourth cervical vertebra, fifth cervical vertebra, sixth cervical vertebra }\end{array}$ \\
\hline Articular (4) & $\begin{array}{l}\text { Intervertebral disc (C II \& C III), intervertebral disc (C III \& C IV), intervertebral disc (C IV \& C V), } \\
\text { intervertebral disc (C V \& C VI) }\end{array}$ \\
\hline Vascular (artery) (18) & $\begin{array}{l}\text { Common carotid artery, external carotid artery, superficial temporal artery, maxillary artery, internal } \\
\text { carotid artery, vertebral artery, anterior cerebral artery, perical losal artery, middle cerebral artery, posterior } \\
\text { communicating artery, posterior cerebral artery, basilar artery }\end{array}$ \\
\hline Vascular (vein) (22) & $\begin{array}{l}\text { Internal jugular vein, transverse sinus, sigmoid sinus, inferior petrosal sinus, superior petrosal sinus, } \\
\text { emissary vein, confluence of sinuses, occipital sinus, superior sagittal sinus, inferior sagittal sinus, straight } \\
\text { sinus, cavernous sinus, diploic vein, superior cerebral vein, inferior cerebral vein, great cerebral vein }\end{array}$ \\
\hline Sensory (eye) (18) & $\begin{array}{l}\text { Cornea and scler a, lens, levator palpebrae superioris, superior rectus, inferior rectus, medial rectus, lateral } \\
\text { rectus, superior oblique muscle, inferior oblique muscle }\end{array}$ \\
\hline Sensory (ear) (18) & $\begin{array}{l}\text { External acoustic meatus, stapes, incus, malleus, auditory tube, cochlea, anterior semicircular duct, } \\
\text { posterior semicircular duct, lateral semicircular duct }\end{array}$ \\
\hline Central nervous (22) & $\begin{array}{l}\text { Substantia nigra, red nucleus, thalamus, cerebral hemisphere, lateral ventricle, caudate nucleus, putamen, } \\
\text { globus pallidus, spinal cord, brainstem, fourth ventricle, cerebellum, corpus callosum, fornix }\end{array}$ \\
\hline $\begin{array}{l}\text { Peripheral nervous } \\
\text { (19) }\end{array}$ & $\begin{array}{l}\text { Optic nerve, oculomotor nerve, ophthalmic nerve, frontal nerve, chorda tympani, abducens nerve, facial } \\
\text { nerve, vestibular nerve, cochlear nerve, optic chiasm }\end{array}$ \\
\hline Endocrine (1) & Pituitary gland \\
\hline
\end{tabular}

The numbers in parentheses are the numbers of structures. 


\section{RESULTS}

The installation file of the full data (resolution 2,070 $X$ 2,064) could be obtained from the website (neuroanatomy.kr). The installation file of the reduced data (resolution $400 \times 458$ ) could be found by typing "browsing software" in the search window of Google Play Store to be downloaded (Fig. 2).

After installing the software at the Google Android operating system version 4.0 or up, the sectioned images could be browsed freely by touching and dragging on the screen of the mobile device with the finger. Using the scroll bar or button on the screen, the images were browsed serially. By inputting the file number (from 001 to 234), the desired image was displayed directly. After magnifying the image, viewing area was moved using the drag function. In a zoomin state, a scroll bar and button could also be used. By double touching a spot of interest, the name of the structure was popped-up according to the text file and the segmented images. By swiping the screen to the right or left, the sectioned image was switched to the corresponding segmented image or vice versa. By pushing the F1 button on the screen, the manual for the software was shown (Fig. 3).

In the Google Play Store, the software that was downloaded by the users from several countries used to be the third ranking in the medical category during the year 2015. There was praise from some clients in the comment section of the Google Play Store (Fig. 4).

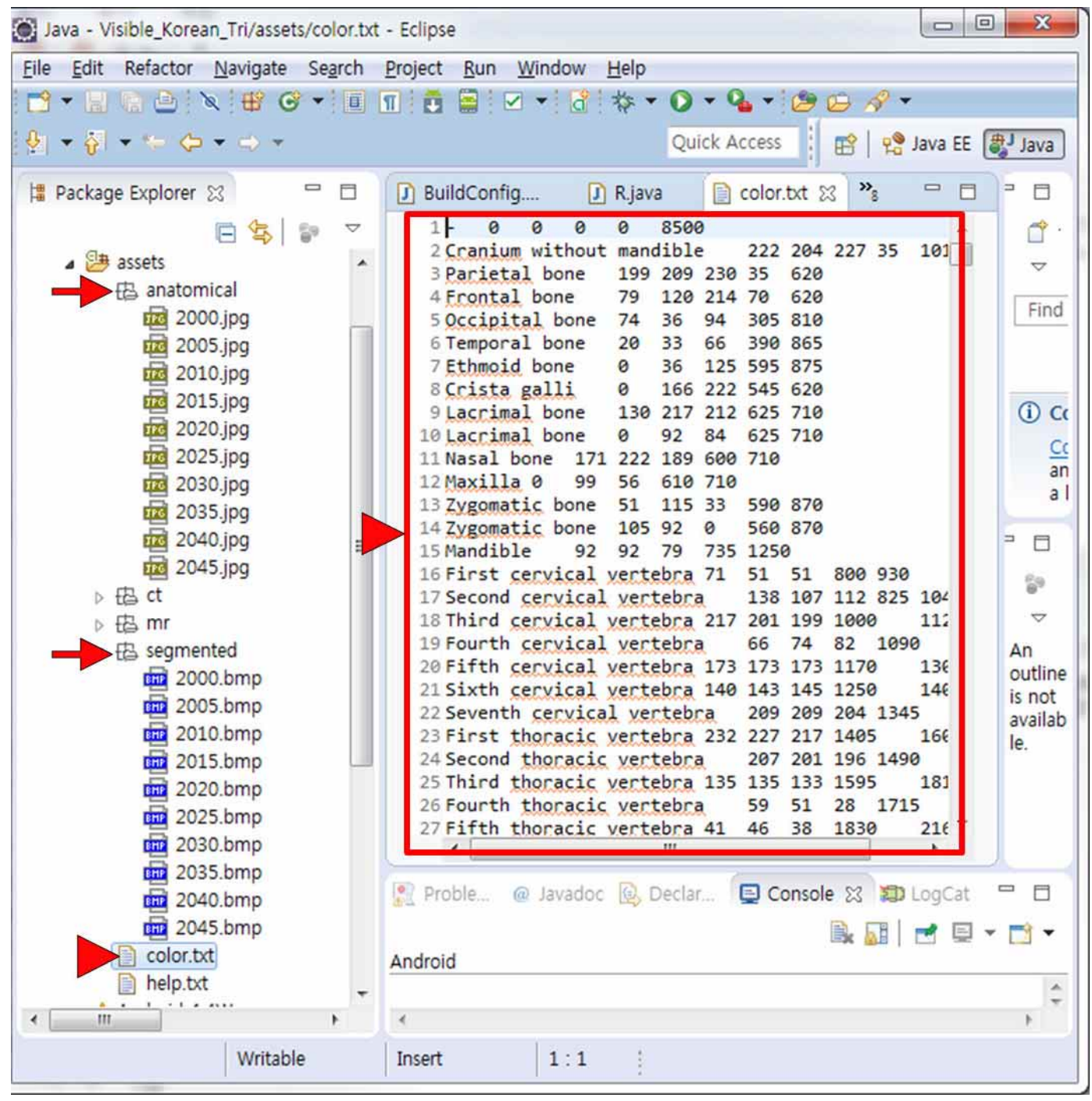

Fig. 1. Folder of sectioned images, folder of segmented images (arrows), and text file about segmented structures (arrow heads). 

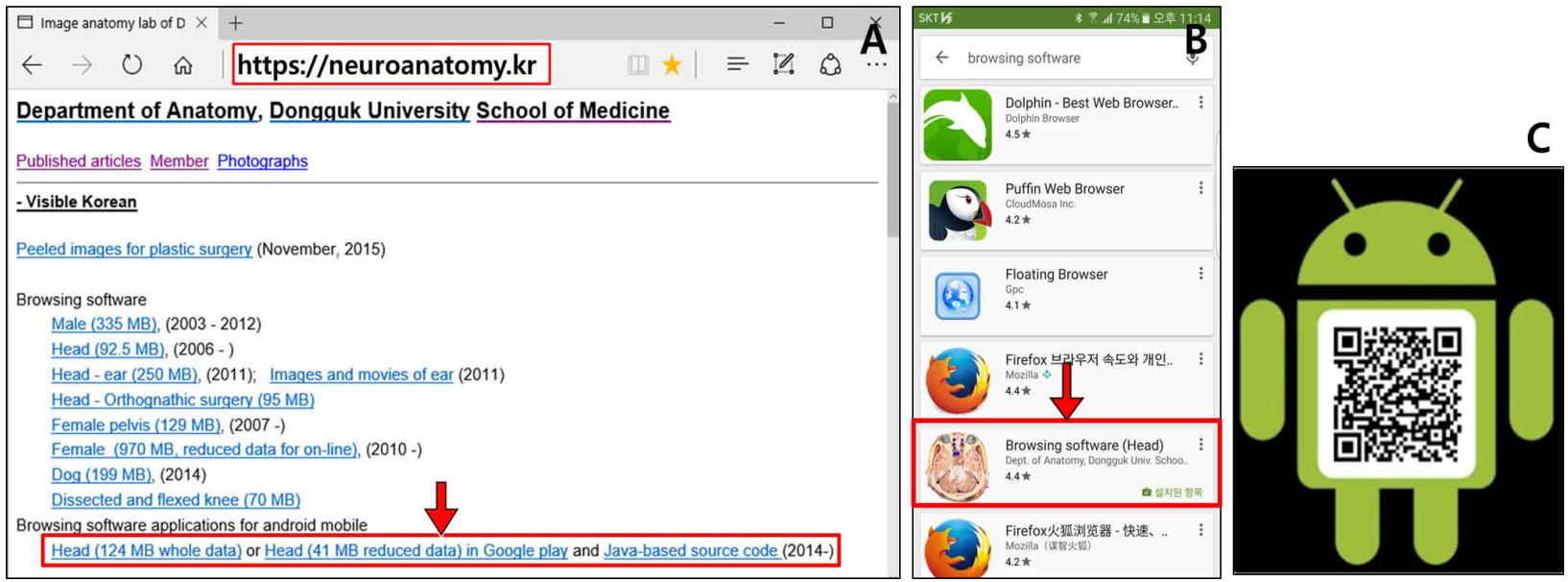

Fig. 2. Homepage (A), Google Play Store (B), and QR code (C), where the installation file is downloadable.
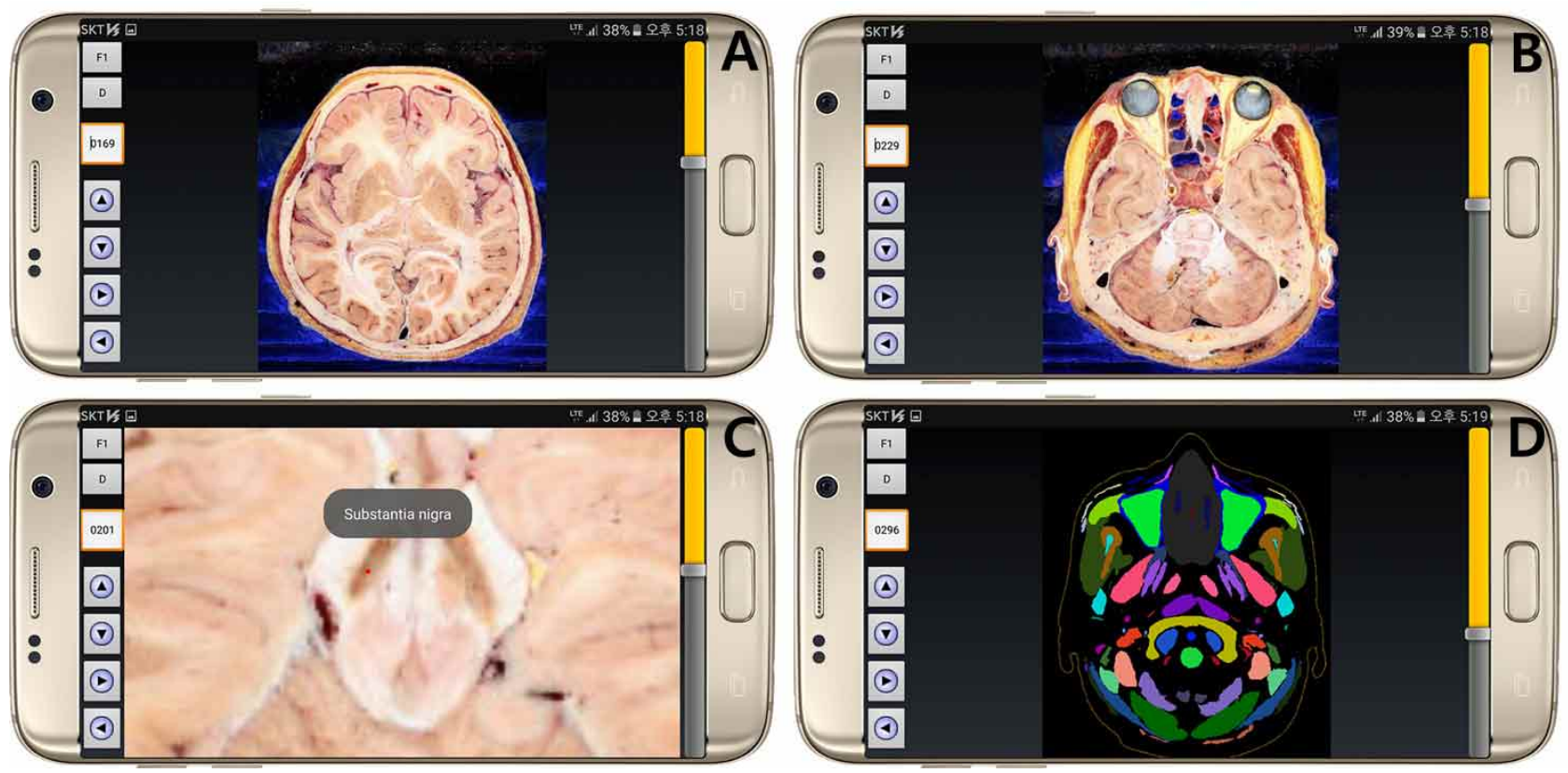

Fig. 3. Screen captures of browsing software on Samsung Galaxy S7 when sectioned images are browsed (A, B); an image is zoomed in; the name of the structure is displayed by double clicking over a specific structure $(\mathrm{C})$; the sectioned image is replaced by the segmented image (D).

\section{DISCUSSION}

The browsing software for an Android mobile device can be utilized regardless of the place and time. An example is medical students learning sectional anatomy of the brain with the horizontally sectioned specimens. Another example is the clinicians, interpreting brain MRIs in the hospital. They may benefit from the mobile device version.

The browsing software on the Android operating system is not for commercial profit (Gandhewar \& Sheikh,
2010). Even if the authors have no plans to make the software on iPhones, the authors will cooperate with anyone who aims to make it. For that, both the source code and all image data will be released.

From the Visible Korean project, several browsing software on personal computers have been made and distributed for free via the homepage (http://neuroanatomy.kr): male whole body (Shin et al., 2011), female pelvis (Shin et 


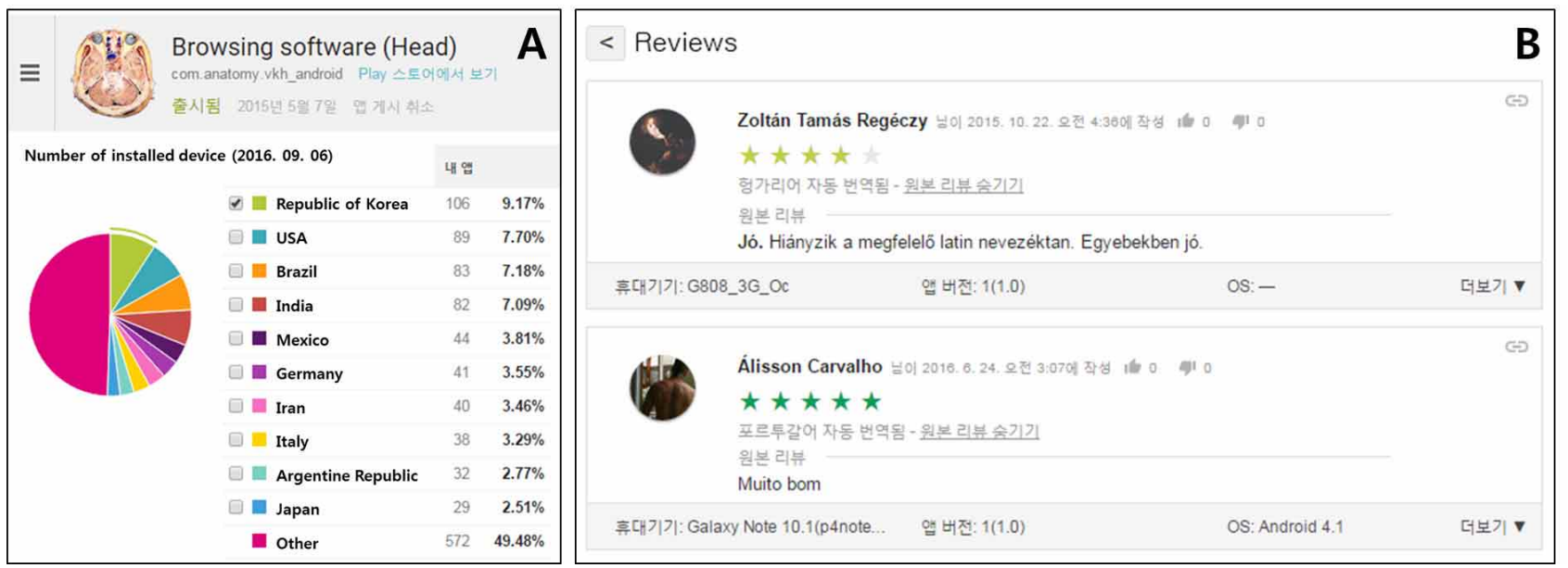

Fig. 4. Countries where the software is downloaded (A) and the responses from the users in Hungary and Portugal (B), which translate into "Good, lack of proper Latin nomenclature. Otherwise good." and "Very good."

al., 2013), and so on. After the installation of the software, the image data (sectioned images and segmented images) can be obtained. The images may be utilized in other browsing software for mobile devices. It is also possible for the users to modify the mobile software to browse their own images. They just need to replace the images and the segmentation data file (color.txt) (Fig. 1).

Any investigator is allowed to manufacture commercial or non-commercial products without the permission of the authors. The only requirement is that the investigators reveal the contribution of Visible Korean in their new software. The mobile version of the browsing software is expected to assist in the learning of sectional anatomy ubiquitously and promote the production of educational software for Android mobile devices.

ACKNOWLEDGEMENTS. The authors gratefully acknowledge the human data support provided by Korea Institute of Science \& Technology Information (KISTI) which produced these data with Ajou University of Medicine.

This work (NRF-2012R1A2A2A01012808) was supported by Mid-career Researcher Program through NRF grant funded by the MEST.

This research was financially supported by the Ministry of Trade, Industry and Energy (MOTIE) and Korea Institute for Advancement of Technology (KIAT) through the International Cooperative R\&D program (Grant number: N0002249).
LEE, S. B.; CHUNG, B. S.; CHUNG, M. S.; YOUN, C. \& PARK, J. S. Software de navegación para el dispositivo móvil Android de imágenes seccionadas de cabeza. Int. J. Morphol., 35(4):1377-1382, 2017.

RESUMEN: El propósito de esta investigación fue permitir que toda persona aprendiera la anatomía de secciones de la cabeza, en cualquier lugar y en cualquier momento, a través de un software para examinar imágenes seccionadas en un dispositivo móvil Android de Google. De las 2.343 imágenes seccionadas a intervalos de $0,1 \mathrm{~mm}$, se seleccionaron 234 imágenes seccionadas a intervalos de $1 \mathrm{~mm}$. Se seleccionaron las 234 imágenes segmentadas que contenían 236 estructuras de cabeza. El software de la versión móvil fue programado y depurado en el lenguaje de programación Java. Las carpetas de las imágenes seccionadas y las imágenes segmentadas y el archivo .txt de los datos de segmentación se organizaron en el código fuente del software. El software se distribuyó gratuitamente en la página principal (neuroanatomy.kr) y Google Play Store. Después de instalar el software, las imágenes seccionadas y las imágenes segmentadas correspondientes se pueden navegar tocando y deslizando la pantalla. En la categoría médica de Google Play Store, el software obtuvo buena recepción. El software de la versión móvil de Android fue utilizado independientemente de la hora y el lugar. El software está bajo la política no comercial de los autores. Otros investigadores pueden modificar el software móvil para navegar por sus propias imágenes. La versión móvil del software ayudará a los estudiantes de medicina y los médicos en el aprendizaje de la anatomía seccional.

PALABRAS CLAVE: Anatomía transversal; Aplicaciones móviles; Smartphone; Proyecto Humano Visible. 


\section{REFERENCES}

Arnold, K.; Gosling, J.; Holmes, D. \& Holmes, D. The Java Programming Language. $4^{\text {th }}$ ed. Boston, Addison-Wesley Professional, 2000.

Butler, M. Android: Changing the mobile landscape. IEEE Pervasive Comput., 10(1):4-7, 2011.

Cho, Z. H.; Kim, Y. B.; Han, J. Y.; Min, H. K.; Choi, S. H.; Chung, M. S.; Park, J. S.; Lee, J. W.; Park, H. S.; Shin, D. S.; Har, D. H.; Cho, D. H.; Chi, J. G.; Park, C. W.; Park, C. W.; Kim, Y. B.; Lee, J. M.; Fallon, J. H.; Na, D. L.; Moon, S. Y.; Seo, S. W.; Kim, S. H. \& Go, S. M. 7.0 Tesla MRI Brain Atlas: In Vivo Atlas with Cryomacrotome Correlation. New York, Dordrecht, Springer, 2009.

Davies, B. S.; Rafique, J.; Vincent, T. R.; Fairclough, J.; Packer, M. H.; Vincent, R. \& Haq, I. Mobile Medical Education (MoMEd) - how mobile information resources contribute to learning for undergraduate clinical students - a mixed methods study. BMC Med. Educ., 12(1):1, 2012.

des Rivières, J. \& Wiegand, J. Eclipse: A platform for integrating development tools. IBM Syst. J., 43(2):371-83, 2004.

Dixon, A. K.; Bowden, D. J.; Ellis, H. \& Logan, B. M. Human Sectional Anatomy: Atlas of Body Sections, CT and MRI Images. $4^{\text {th }}$ ed. Boca Raton, CRC Press, 2015.

Franko, O. I. \& Tirrell, T. F. Smartphone app use among medical providers in ACGME training programs. J. Med. Syst., 36(5):3135-9, 2012.

Gandhewar, N. \& Sheikh, R. Google Android: An emerging software platform for mobile devices. Int. J. Comput. Sci. Eng., 1(1):12-7, 2010.

Park, J. S.; Chung, M. S.; Hwang, S. B.; Lee, Y. S. \& Har, D. H. Technical report on semiautomatic segmentation using the Adobe Photoshop. $J$. Digit. Imaging, 18(4):333-43, 2005.

Park, J. S.; Chung, M. S.; Shin, D. S.; Har, D. H.; Cho, Z. H.; Kim, Y. B.; Han, J. Y \& Chi, J. G. Sectioned images of the cadaver head including the brain and correspondences with ultrahigh field 7.0 T MRIs. Proc. IEEE., 97(12):1988-96, 2009

Rohilla, J.; Rohilla, R.; Rohilla, A. \& Singh, K. Academic use and attitude of the 1st year medical students toward smartphones in a North Indian city. Digit. Med., 2(1):13-6, 2016.

Shin, D. S.; Chung, M. S.; Park, H. S.; Park, J. S. \& Hwang, S. B. Browsing software of the Visible Korean data used for teaching sectional anatomy. Anat. Sci. Educ., 4(6):327-32, 2011.

Shin, D. S.; Jang, H. G.; Hwang, S. B.; Har, D. H.; Moon, Y. L. \& Chung, M. S. Two-dimensional sectioned images and three-dimensional surface models for learning the anatomy of the female pelvis. Anat. Sci. Educ., 6(5):316-23, 2013.

Shin, D. S.; Jang, H. G.; Park, J. S.; Park, H. S.; Lee, S. \& Chung, M. S. Accessible and informative sectioned images and surface models of a cadaver head. J. Craniofac. Surg., 23(4):1176-80, 2012.

Spitzer, V. M. \& Whitlock, D. G. National Library of Medicine: Atlas of the Visible Human Male: Reverse Engineering of the Human Body. Burlington, Jones \& Bartlett Learning, 1997.

\author{
Corresponding author: \\ Jin Seo Park \\ Department of Anatomy \\ College of Medicine \\ Dongguk University \\ 87 Dongdae-ro, Gyeongju, 38067 \\ REPUBLIC OF KOREA
}

Email: park93@dongguk.ac.kr

Received:06-07-2017

Accepted:06-09-2017 